\title{
The sector accounts
}

The sector accounts show the relationships between different sectors of the economy and different types of transactions. They summarise the transactions of particular groups of institutions in the economy, showing how income is distributed and redistributed, and how savings are used to add wealth through investment in physical or financial assets. This section introduces the tables in Chapters 3 to 7 which deal with individual areas and subdivisions of the accounts. This introduction to the sector accounts has been divided into the following areas:

- The framework of the accounts

- The institutional sectors

- The types of transactions

- The sequence of accounts

- The statistical adjustment items

- Balance sheets

\section{The framework of the accounts}

The framework of national accounts detailed in Part 1 highlights the five main kinds of accounts; goods and services, production, distribution and use of income, capital, and financial. The production account records the activity of producing goods and services. The distribution and use of income accounts record how incomes are generated by production, distributed to institutional units with claims on the value added created by production, redistributed among institutional units, and eventually used by households, government units or non-profit institutions serving households for purposes of final consumption or saving. The capital account records the flows of non-financial assets acquired and disposed. The financial account shows how the net lending or borrowing on the capital account is financed by transactions in financial instruments.

The distribution and use of income accounts can be elaborated to form a consistent set of sector accounts. This is done in two dimensions, by sectors and types of transaction. A third dimension, related to capital and financial transactions is that of asset and liability levels, the national and sector balance sheets. The sectors and types of transaction are described below.

\section{The institutional sectors}

The system identifies two kinds of institutions: consuming units (mostly households); and production units (mainly corporations and non-profit institutions or government). Units can own goods and assets, incur liabilities and engage in economic activities and transactions with other units in their own right. All units within the country are put in one of the sectors. Also, the rest of the world is treated as a sector in respect of its dealings with the UK.

Non-financial corporations are those which exist to produce goods and non-financial services. They are, in the UK, mainly public limited companies, private companies and partnerships. They are mostly owned privately, but there are some public corporations, which are shown separately.

Financial corporations are those engaged primarily in financial activities, and are subdivided into monetary financial institutions, other financial intermediaries and financial auxiliaries, and insurance corporations and pension funds.

General government comprises central government and local government.

The household sector contains all the resident people of the UK as receivers of income and consumers of products. It includes individuals such as prisoners as well as conventional family units. It also contains one person businesses where household and business accounts cannot be separated. This sector currently includes non-profit institutions serving households, which include productive units such as charities and universities.

The rest of the world sector comprises those units that are not in the UK. The accounts for the rest of the world only record transactions between units in the rest of the world and units in the UK, and are equivalent to the balance of payments

The tables in Chapters 3 to 7 are based on the sector classification detailed above. More detailed definitions of these sectors are given in the appropriate chapters of the publication UK National Accounts Concepts, Sources and Methods and, in full detail, in the Business Monitor MA23 Sector Classification for the National Accounts available from the ONS website.

\section{The types of transactions}

Transactions are divided into three types.

Transactions in products are related to goods and services, and include output, intermediate and final consumption, gross capital formation and exports and imports.

Distributive transactions transfer income or wealth between units of the economy, and include property income, taxes and subsidies, social contributions and benefits, and other current or capital transfers. 
Financial transactions differ from distributive transactions in that they relate to transactions in financial claims by one unit on another, whereas distributive transactions are unrequited. The main categories in the classification of financial instruments are monetary gold and special drawing rights, currency and deposits, securities other than shares, loans, shares and other equity, insurance and pension funds reserves and other accounts receivable/payable.

\section{The sequence of accounts}

The transactions can be grouped broadly according to purpose in the production, distribution and use of income, capital or financial accounts. These are described briefly below:

\section{Production account}

The production account displays the transactions involved in the generation of income by the production of goods and services. This account is produced for the UK total economy (Table 1.6.1) and for the first four sectors (Tables 3.1.1, 4.1.1 etc.); the rest of the world does not have a production account. For each of the four sectors, the balancing item gross value added is shown as output less intermediate consumption. Gross value added at basic prices for each sector differs from gross domestic product for the UK total economy in that taxes less subsidies on products are not taken into the production accounts by sector but they are included within resources for the UK total economy. The sum of gross value added and taxes less subsidies on products for the UK economy is GDP at market prices.

\section{Distribution and use of income account}

The distribution and use of income accounts exist for all the main institutional sectors. To obtain the disposable income and savings of each sector we need to take account of transfers in and out of the sector. The accounts are not consolidated, so that in the whole economy account, transfers such as social contributions and benefits appear in both uses and resources.

These accounts describe the distribution and redistribution of income and its use in the form of final consumption. The distribution and use of income are analysed in four stages, each of which is presented as a separate account:

- The generation of income account

- The allocation of primary income account

- The secondary distribution of income account

- The use of disposable income account

\section{Generation of income account}

This is the first of the distribution and use of income accounts. It shows the sectors, sub-sectors and industries which are the source, rather than the destination, of income. It shows the derivation of the 'profit' arising from production, called the operating surplus (or mixed income in the case of unincorporated businesses in the households sector). The industry dimension is shown in Part 2, Table 2.1.

This account analyses the degree to which value added covers the compensation of employees (such as their wages and salaries) and other taxes less subsidies on production. So it gives a figure for the operating surplus: the surplus (or deficit) on production activities before distributions such as interest, rent and income tax charges have been considered. Hence the operating surplus is the income which units obtain from their own use of the production facilities.

Note that taxes on production and imports are shown as a use by producing sectors in this account but not as a resource of government. This is because they do not relate to productive activity by government, and cannot therefore contribute to its operating surplus. They become a resource of government in the allocation of primary income account which follows.

\section{Allocation of primary income account}

This account shows the resident units and institutional sectors as recipients rather than producers of primary income. It demonstrates the extent to which operating surpluses are distributed (for example by dividends) to the owners of the enterprises. Also recorded in this account is the property income received by an owner of a financial asset in return for providing funds to, or putting a tangible non-produced asset at the disposal of, another unit. The receipt by government of taxes on production less subsidies is shown in resources.

The resources side of the allocation of primary income accounts includes the components of the income approach to measurement of gross domestic product and this is the starting point for the quarterly sector accounts. The accounts also include property income recorded as both resources for receipts and uses for payments.

The balance of this account is the gross balance of primary income (line B.5g) for each sector, and if the gross balance of primary income is aggregated across all sectors of the UK economy the result is gross national income.

\section{Secondary distribution of income account}

This account describes how the balance of primary income for each institutional sector is allocated by redistribution; through transfers such as taxes on income, social contributions and benefits and other current transfers. It excludes social transfers in kind.

The balancing item of this account is gross disposable income (B.6g) which reflects current transactions and explicitly excludes 
capital transfers, real holding gains and losses, and the consequences of events such as natural disasters.

\section{Use of disposable income account}

This account illustrates how disposable income is split between final consumption expenditure and saving. In the system for recording economic accounts, only the government and the households and NPISH sectors have final consumption. In addition, for households and pension funds, there is an adjustment item in the account which reflects the way that transactions between households and pension funds are recorded. (This adjustment is D.8: Adjustment for the changes in the net equity of households in pension funds reserves.)

The balancing item for this account, and thus for this whole group of distribution and use of income accounts, is gross saving (B.8g).

Thus it is only in the case of non-financial corporations (public and private), that undistributed income and saving are equivalent.

\section{Capital account}

The capital account is presented in two parts.

The first part shows that saving (B.8g) - the balance between national disposable income and final consumption expenditure from the production and distribution and use of income accounts - is reduced or increased by the balance of capital transfers (D.9) to provide an amount available for financing investment (in both non-financial and financial assets).

Then in the second part, total investment in non-financial assets is the sum of gross fixed capital formation (P.51), changes in inventories (P.52), acquisitions less disposals of valuables (P.53) and acquisitions less disposals of non-financial non-produced assets (K.2). The balance on the capital account is known as net lending or borrowing. Conceptually this net lending or borrowing for all the domestic sectors represents net lending or borrowing to the rest of the world sector.
Thus, if investment is lower than the amount available for investment, the balance will be positive and is regarded as lending (if negative the balance is borrowing). Where the capital accounts relate to the individual institutional sectors, the net lending/borrowing of a particular sector represents the amounts available for lending or borrowing to other sectors. The value of net lending/borrowing is the same irrespective of whether the accounts are shown before or after deduction of fixed capital consumption (K.1), provided a consistent approach is adopted throughout.

\section{Financial account}

The financial account elaborates the acquisition and disposal of financial assets and liabilities. Examples of financial assets include: bank deposits (which are assets of the depositors and liabilities of the banks), unit trust units (assets of the holders and liabilities of unit trusts) and Treasury Bills (assets of the holders and a liability of central government). The balance of all transactions in the financial account is net lending or borrowing.

\section{The statistical adjustment items}

Although in theory the net lending/borrowing from the financial account and the net lending/borrowing from the capital account for each sector should be equal, in practice they are not. This is because of the (sometimes substantial) errors and omissions in the accounts. The difference between the two balances is known as the statistical adjustment item.

Part of the balancing process for the economic accounts statistics for years before the latest one shown (that is, for years t-1 and earlier) involves assessing and modifying the component variables so that the estimates of net lending/ borrowing made from the income and capital accounts, and from the financial accounts, are the same at the level of the whole economy, and reasonably close to each other at the sector level.

The sectoral statistical adjustment items are shown in Table D below. They provide a measure of the reliability of the accounts.

\section{Dable D: Sector statistical adjustment}

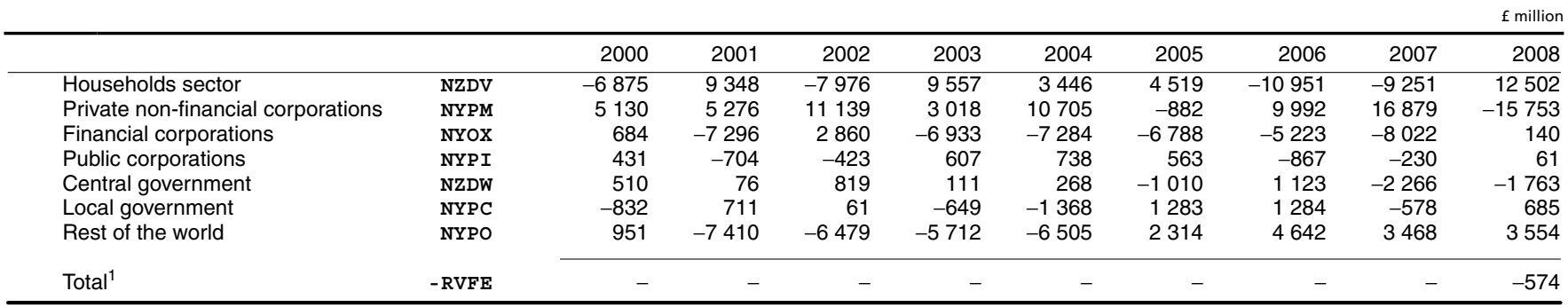

1 Equals, but opposite in sign to, the residual error observed between GDP measured by the income approach and GDP measured by the expenditure approach 


\section{Balance sheets}

A financial balance sheet for each sector has been compiled using the same financial instrument classification as that used for financial transactions. The changes in the end period levels in the financial balance sheets do not equal the financial transactions because of holding gains or losses and reclassifications of units between sectors. Non-financial balance sheets for the ESA95 sectors are now included.

\section{Further information}

In addition to the articles and publications mentioned in Part 1, further information relating to the sector accounts and in particular the financial accounts can be found in the following articles and publications:

Office for National Statistics (2007) Financial Statistics: Explanatory Handbook 2009 edition, Palgrave Macmillan, Basingstoke.

Office for National Statistics Financial Statistics, monthly publication, Palgrave Macmillan, Basingstoke.
Turnbull P (Central Statistical Office) (1993) 'The UK Sector Accounts' Economic Trends, No. 479, HMSO.

Bank of England (2002) Bank of England Statistical Abstract Bank of England.

\section{Articles relating to the Public Sector Finances} Golland J, Savage D, Pike T and Pike S (1999) 'Monthly Statistics on Public Sector Finances. A Methodological Guide', GSS Methodology Series no. 12, Office for National Statistics.

Golland J, Louth N, Hill C (1998) 'New Format For Public Finances' Economic Trends, No. 535, The Stationery Office.

Articles relating to monetary aggregates (M0, M4) Bank of England (1994) 'The Determination of M0 and M4' Bank of England Quarterly Bulletin February 1994, pages 46-50.

Bank of England (1993) 'Divisia measures of money' Bank of England Quarterly Bulletin, May 1993. 